\title{
Impact of acute exposure to air pollution on the cardiorespiratory performance of military firemen
}

R.S. Oliveira ${ }^{1,2,3}$, T.L. Barros Neto ${ }^{2}$, A.L.F. Braga ${ }^{4,6,7}$, V. Raso ${ }^{5}$, L.A.A. Pereira ${ }^{4,7}$, S.R. Morette ${ }^{2}$ and R.C. Carneiro ${ }^{2}$

\author{
${ }^{1}$ Escola de Educação Física, Polícia Militar do Estado de São Paulo, São Paulo, SP, Brasil \\ ${ }^{2}$ Centro de Medicina da Atividade Física e do Esporte, Escola Paulista de Medicina, \\ Universidade Federal de São Paulo, São Paulo, SP, Brasil \\ ${ }^{3}$ Centro de Estudos de Enfermagem e Nutrição, Universidade Católica de Goiás, \\ Goiânia, GO, Brasil \\ ${ }^{4}$ Núcleo de Estudos em Epidemiologia Ambiental, Laboratório de Poluição Atmosférica \\ Experimental, ${ }^{5}$ Departamento de Fisiopatologia Experimental, Faculdade de Medicina, \\ Universidade de São Paulo, São Paulo, SP, Brasil \\ ${ }^{6}$ Programa de Pediatria Ambiental, Faculdade de Medicina, Universidade de Santo \\ Amaro, Santo Amaro, SP, Brasil \\ ${ }^{7}$ Programa de Pós-graduação em Saúde Coletiva, Universidade Católica de Santos, \\ Santos, SP, Brasil
}

\section{Correspondence R.S. Oliveira \\ Escola de Educação Física Polícia Militar do Estado de São Paulo \\ Av. Cruzeiro do Sul, 548 03033-020 São Paulo, SP Brasil \\ Fax: +55-11-3229-3622 \\ E-mail: raulsanto@polmil.sp.gov.br \\ Research partially supported by the São Paulo State Police and the School of Physical Education of the São Paulo State Police.}

Publication supported by FAPESP.

Received February 6, 2006 Accepted September 11, 2006

\begin{abstract}
The objective of the present study was to determine the impact of acute short-term exposure to air pollution on the cardiorespiratory performance of military fireman living and working in the city of Guarujá, São Paulo, Brazil. Twenty-five healthy non-smoking firemen aged 24 to 45 years had about $1 \mathrm{~h}$ of exposure to low and high levels of air pollution. The tests consisted of two phases: phase A, in Bertioga, a town with low levels of air pollution, and phase B, in Cubatão, a polluted town, with a 7-day interval between phases. The volunteers remained in the cities (Bertioga/Cubatão) only for the time required to perform the tests. Cumulative load $10 \pm 2$ min-long exertion tests were performed on a treadmill, consisting of a 2-min stage at a load of $7 \mathrm{~km} /$ $\mathrm{h}$, followed by increasing exertion of $1 \mathrm{~km} \mathrm{~h}^{-1} \mathrm{~min}^{-1}$ until the maximum individual limit. There were statistically significant differences $(\mathrm{P}<0.05)$ in anaerobic threshold (AT) between Cubatão $(35.04 \pm 4.91$ $\left.\mathrm{mL} \mathrm{kg}{ }^{-1} \mathrm{~min}^{-1}\right)$ and Bertioga $\left(36.98 \pm 5.62 \mathrm{~mL} \mathrm{~kg}^{-1} \mathrm{~min}^{-1} ; \mathrm{P}=0.01\right)$, in the heart rate at $\mathrm{AT}\left(\mathrm{AT}_{\mathrm{HR}}\right.$; Cubatão $152.08 \pm 14.86 \mathrm{bpm}$, Bertioga $157.44 \pm 13.64 \mathrm{bpm} ; \mathrm{P}=0.001)$, and in percent maximal oxygen consumption at AT $\left(\mathrm{AT} \% \mathrm{VO}_{2 \max }\right.$; Cubatão $64.56 \pm 6.55 \%$, Bertioga $67.40 \pm 5.35 \% ; \mathrm{P}=0.03)$. However, there were no differences in $\mathrm{VO}_{2 \max }$, maximal heart rate or velocity at $\mathrm{AT}\left(\mathrm{AT}_{\mathrm{vel}}\right)$ observed in firemen between towns. The acute exposure to pollutants in Cubatão, $\mathrm{SP}$, caused a significant reduction in the performance at submaximal levels of physical exertion.
\end{abstract}

Key words

- Air pollution

- Firemen

- Cardiorespiratory

performance

- Cardiopulmonary exercise testing 


\section{Introduction}

Although much has been discussed regarding the improvement of quality of life with regular physical exercise, few studies are available about the cardiorespiratory response evaluated on the basis of $\mathrm{O}_{2}$ uptake, transport, and utilization in areas with high concentrations of pollutants in the atmosphere (1-3). Mostly in large urban centers and industrial areas, "in the fight for health and longevity", people are forced to exercise in areas with inadequate conditions, extreme temperatures, little ventilation, low impact absorption soil, and, above all, a direct contact with air pollution (4).

In the South American winter, this scenario becomes worse due to thermal inversions that impair the dispersion of pollutants, with frequently inadequate air quality standards. The World Health Organization estimates that more than 1.5 billion people may be living in areas where the air contamination exceeds the recommendation limits (5).

Studies have shown that the air of São Paulo city induces damage to the respiratory tract of rats. The chronic exposure of these animals to the air of downtown São Paulo produced an inflammatory process in respiratory tissue extending from the upper airways to the pulmonary alveoli (6).

There are also studies supporting the idea that the life expectancy of the population is affected by air pollution levels $(7,8)$. Many studies have reported an association between the increase of atmospheric pollution and the number of hospital admissions due to respiratory and cardiovascular diseases in different age groups (9-14). The effects of pollution on health were usually observed in an acute short time exposure $(11,15,16)$.

The impact of air pollution has also been assessed in terms of impairment of physical performance. Reduction in maximal oxygen consumption and endurance time and failure to complete an exercise have been associ- ated with exposure to air pollutants $(2,17$ 19). Exposure to $\mathrm{O}_{3}$ during physical exercises induced toxicity, troubled breathing, headaches, and a reduction of forced expiratory volume (2). Exhaustive exercising performed for $30 \mathrm{~min}$ in high traffic areas has been estimated to be equivalent to smoking 10 cigarettes (20).

Few studies are available about the effects of air pollution on people who practice regular physical activities. Thus, the present study was designed to evaluate the impact of brief acute exposure to polluted atmospheric air on the cardiorespiratory performance of military firemen in coastal Brazilian cities with a well-known air pollution status, i.e., Cubatão, a city with high industrial and automotive activities, and Bertioga, a city with very low levels of air pollution.

\section{Volunteers, Material and Methods}

\section{Volunteers}

The sample consisted of 25 clinically healthy young adult males between 24 and 45 years of age, members of the active shift of the State of São Paulo fireman department of the Military Police and selected among 40 volunteers to participate in this study. The sample was defined as a non-probabilistic sample because we worked with all available subjects. All volunteers resided and worked in the city of Guarujá on the coast of the State of São Paulo, and were informed of the objective of this study, as well as its benefits and possible dangers to health. The participation in the study was voluntary and the individuals were allowed to withdraw from it at any time. After this orientation, each subject signed an informed term of consent. The Medical Ethics Committee of the Federal University of São Paulo approved the study.

The volunteers were submitted to clinical, nutritional and physical evaluation. The inclusion criteria were: a) being approved in 
the physical capacity test (Cooper test of 12 min, 50-m velocity test, and number of abdominal exercises in $1 \mathrm{~min}$ ); b) being a nonsmoker; c) residing and working in the city of Guarujá; d) practicing regular physical activities, and e) being free of any cardiovascular or pulmonary disease. The exclusion criteria were: a) presenting any type of orthopedic limitation indicated by a physician; b) using any kind of medication; c) being younger than 20 years or older than 45 years; d) presenting any health problems that prevented maximum effort on the treadmill. On the basis of these criteria, 25 of 40 subjects were included in the study.

\section{Experimental design}

Volunteers were assigned a sequential number at the time of enrollment. Four groups of volunteers were defined and each group was assigned to one day of the week, from Tuesday to Friday, following the sequential numbers. The weekday of the test for each volunteer was the same in both cities. There was no control (or placebo) group.

Tests were performed in two phases: phase $\mathrm{A}$ was performed in the city of Bertioga and phase B in the city of Cubatão with a 7day interval between phases. Bertioga is located $30 \mathrm{~km}$ from Guarujá and its economy is based on tourism. In fact, the town is located in a State Park which is under strict environmental control. Although there are no conventional instrumental measurements of air quality in Bertioga, there is solid evidence that air quality is good, as indicated by lichen biodiversity (21). On the other hand, Cubatão is a heavily polluted industrial town, with 22 industries mainly in the petrochemical and steel areas. Despite the efforts to improve air quality in Cubatão, its particular geographic location does not favor the dispersion of air contaminants. Daily measurements of $\mathrm{PM}_{10}, \mathrm{O}_{3}, \mathrm{SO}_{2}$, and $\mathrm{NO}_{2}$ are performed in Cubatão by the São Paulo State Sanitation Agency (CETESB) (21).
The order of the cities was defined at random. Each volunteer was picked up at the firemen unit in Guarujá and taken to the city under study (Bertioga and Cubatão) on his respective day of the week. After the test, volunteers returned to the firemen unit to resume their professional duties and for this reason they could not be exposed for a longer period of time.

Each volunteer was submitted to cardiopulmonary exercise testing (CPX) at increasing loads on a Precor ${ }^{\mathrm{TM}}$ treadmill (C-Model 964i, Woodinville, WA, USA) equipped with a Vacumed ${ }^{\mathrm{TM}}$ gas exchange analyzer (Ventura, CA, USA) and a computerized metabolic system (Model Vista Mini CPX, silver edition, Ventura, CA, USA). Heart rate was monitored with a Polar ${ }^{\mathrm{TM}}$ frequency counter (Model Protrainer NV, Kempele, Finland).

Physiological variables were determined at 30-s intervals in both phases. Blood pressure was measured during the test as a safety procedure. The gas exchange analyzer was calibrated for each test in the morning and in the evening according to ambient air and a standard mixture of $17 \% \mathrm{O}_{2}$ and $5 \% \mathrm{CO}_{2}$.

The firemen warmed up and stretched for $10 \mathrm{~min}$. Next, they put on the frequency counter and the gas exchange analyzer mask and heart rate and blood pressure were measured for $2 \mathrm{~min}$ at rest. The CPX protocol followed the standards determined by the Center of Sport and Physical Activity Medicine (22). The average duration of CPX was $10 \pm 2 \mathrm{~min}$, with increasing loads being applied. The first stage lasted $2 \mathrm{~min}$ at a velocity of $7 \mathrm{~km} / \mathrm{h}$, followed by an increase of $1 \mathrm{~km} / \mathrm{h}$ per min until the individual reached his maximal limit. The environmental temperature, measured with a dry bulb thermometer in climatically controlled areas, was 20 to $25^{\circ} \mathrm{C}$. The relative humidity of the air was measured with a wet bulb thermometer and ranged from 60 to $80 \%$. The atmospheric pressure was $760 \mathrm{mmHg}$ at zero altitude.

Maximal oxygen consumption $\left(\mathrm{VO}_{2 \max }\right)$ 
was considered to be the highest value of this variable attained during the $\mathrm{CPX} . \mathrm{VO}_{2 \max }$ was considered to have occurred when at least two of the following criteria were met: 1) an increase of $\mathrm{VO}_{2}$ during the final phase of exercise of less than $150 \mathrm{~mL}$ or $2.1 \mathrm{~mL} \mathrm{~kg}^{-1}$ $\mathrm{min}^{-1}$ for a $2.5 \%$ increase in treadmill velocity; 2) an increase of $\mathrm{VO}_{2}$ of less than 2 $\mathrm{SD}$ of the average differences between the intensities of the previous exercises; 3) an increase of $\mathrm{VO}_{2}$ of less than $2 \mathrm{~mL} \mathrm{~kg}^{-1} \mathrm{~min}^{-1}$ for an increase of 5 to $10 \%$ in the intensity of exercise; 4) reaching the individual age-predicted maximal heart rate, and 5) a respiratory exchange ratio $\geq 1.1$ (23).

Maximal heart rate was considered to be the highest value reached during the test. The ventilatory anaerobic threshold (AT) was considered to be a visual non-linear elevation point of pulmonary ventilation, inflection point of oxygen ventilatory equivalent $\left(\mathrm{VE} / \mathrm{VO}_{2}\right)$, and a non-linear increase of $\mathrm{CO}_{2}$ production in parallel to $\mathrm{O}_{2}$ consumption $\left(\mathrm{VO}_{2}\right)$ (24). The establishment of the heart rate $\left(\mathrm{AT}_{\mathrm{HR}}\right)$, velocity $\left(\mathrm{AT}_{\mathrm{vel}}\right)$ as well as of the percentage of $\mathrm{VO}_{2 \max }\left(\mathrm{AT} \% \mathrm{VO}_{2 \max }\right)$ at anaerobic threshold were derived from that point in which each one of these variables (heart rate, velocity and the $\mathrm{VO}_{2 \max }$ )

Table 1. Cardiovascular performance variables of young adults in a polluted environment (Cubatão) and in a relatively clean environment (Bertioga).

\begin{tabular}{lcccc}
\hline & \multicolumn{2}{c}{ Bertioga } & \multicolumn{2}{c}{ Cubatão } \\
\hline $\mathrm{VO}_{2 \mathrm{max}}$ & $54.82 \pm 8.37$ & $38.48-68.42$ & $54.50 \pm 7.31$ & $44.09-66.30$ \\
$\left(\mathrm{~mL} \mathrm{~kg} \mathrm{~min}^{-1}\right)$ & & & & \\
$\mathrm{MHR}(\mathrm{bpm})$ & $188.76 \pm 10.33$ & $173.00-206.00$ & $189.12 \pm 9.8$ & $171.00-206.00$ \\
$\mathrm{AT}$ & $36.98 \pm 5.62$ & $25.10-46.93$ & $35.04 \pm 4.91^{*}$ & $31.07-45.07$ \\
$\left(\mathrm{~mL} \mathrm{~kg}{ }^{-1} \mathrm{~min}^{-1}\right)$ & & & & \\
AT $_{\mathrm{HR}(\mathrm{bpm})}$ & $157.44 \pm 13.64$ & $125.00-178.00$ & $152.08 \pm 14.86^{*}$ & $129.00-180.00$ \\
AT $_{\text {vel }}(\mathrm{km} / \mathrm{h})$ & $10.76 \pm 1.51$ & $8.00-14.00$ & $10.56 \pm 1.39$ & $8.00-14.00$ \\
AT\%VO $_{2 m a x}$ & $67.40 \pm 5.35$ & $52.00-78.00$ & $64.56 \pm 6.55^{*}$ & $51.00-75.00$ \\
\end{tabular}

Data are reported as mean \pm SD and range for 25 healthy male adults who exercised in both cities. $\mathrm{VO}_{2 \max }=$ maximal oxygen consumption; $\mathrm{MHR}=$ maximal heart rate; $\mathrm{AT}$ $=$ anaerobic threshold; $\mathrm{AT}_{\mathrm{HR}}=$ heart rate at anaerobic threshold; $\mathrm{AT}_{\mathrm{vel}}=$ velocity at anaerobic threshold; $\mathrm{AT} \% \mathrm{VO}_{2 \max }=$ percent maximal oxygen consumption at anaerobic threshold.

${ }^{*} \mathrm{P}<0.05$ compared to Bertioga (paired $t$-test). attained the anaerobic threshold during the increasing load in CPX. The anaerobic threshold for heart rate $\left(\mathrm{AT}_{\mathrm{HR}}\right)$, velocity $\left(\mathrm{AT}_{\text {vel }}\right)$ and $\mathrm{AT} \% \mathrm{VO}_{2 \max }$ was determined on the basis of the point when each of these variables reached AT while the load was increased.

Tests were carried out by the same person in both cities. Blinding the technician for the city and the volunteer was not possible. The results of the performances were recorded and validated by a researcher blinded to the city of the test. Volunteers were not informed about the results of each test until the end of the field phase of the study.

Descriptive analyses were adopted for demographic and performance variables. Differences between groups were tested by the paired $t$-test after the determination of the normality of the distributions with the Kolmogorov-Smirnov. Pearson's correlation was employed to determine the association level in the cardiopulmonary parameters between the distinct cities.

\section{Results}

The age, weight and height of the 25 individuals studied were not different. Mean age was $31.64 \pm 6.65$ years, mean weight was $78.00 \pm 8.79 \mathrm{~kg}$, and mean height was $176.92 \pm 5.13 \mathrm{~cm}$.

Table 1 shows the descriptive analyses of the performance variables and the level of significance of the paired $t$-test. $M e a n \mathrm{VO}_{2 \max }$ values were $54.50 \pm 7.31 \mathrm{~mL} \mathrm{~kg}^{-1} \mathrm{~min}^{-1}$ when the test was performed in the city of Cubatão and $54.82 \pm 8.37 \mathrm{~mL} \mathrm{~kg}^{-1} \mathrm{~min}^{-1}$ when the test was performed in the city of Bertioga. Mean maximal heart rate was $189.12 \pm 9.8$ bpm in Cubatão and $188.66 \pm$ $10.33 \mathrm{bpm}$ in Bertioga. Mean $\mathrm{AT}_{\mathrm{vel}}$ was $10.56 \pm 1.39 \mathrm{~km} / \mathrm{h}$ in Cubatão and $10.76 \pm$ $1.51 \mathrm{~km} / \mathrm{h}$ in Bertioga, with no statistically significant differences between parameters in each city.

Mean AT values were $35.04 \pm 4.91 \mathrm{~mL}$ $\mathrm{kg}^{-1} \mathrm{~min}^{-1}$ in Cubatão and $36.98 \pm 5.62 \mathrm{~mL}$ 
$\mathrm{kg}^{-1} \mathrm{~min}^{-1}$ in Bertioga $(\mathrm{P}=0.01) . \mathrm{AT}_{\mathrm{HR}}$ was $152.08 \pm 13.64$ bpm in Cubatão and 157.44 $\pm 14.86 \mathrm{bpm}$ in Bertioga $(\mathrm{P}=0.001)$. $\mathrm{AT} \% \mathrm{VO}_{2 \max }$ was $64.56 \pm 6.55 \%$ in Cubatão and $67.40 \pm 5.35 \%$ in Bertioga $(\mathrm{P}=0.03)$. These three variables showed a significant difference between cities by the paired $t$-test.

Figure $1 \mathrm{~A}, \mathrm{~B}$ and $\mathrm{C}$ show the correlation between Cubatão and Bertioga for the three variables that presented statistically significant differences (AT, $\mathrm{AT}_{\mathrm{HR}}$, and $\mathrm{AT} \%$ $\left.\mathrm{VO}_{2 \max }\right)$. The correlations were better for the data obtained in Bertioga than those in Cubatão.

\section{Discussion}

The purpose of the present study was to determine if a brief acute exposure to environmental levels of air pollution interferes with objective indicators of cardiopulmonary function during exercise. In fact, most of the acute effects of air pollution on health have been obtained for individuals with previous respiratory or cardiovascular diseases. However, exercise is a condition that increases the dose of inhaled pollution (2), thus making it plausible that even healthy and fit people may experience significant effects of pollution due to the increased load received.

CPX has been widely employed as a parameter to establish functional capacity and to distinguish cardiopulmonary abnormalities in apparently healthy individuals or in patients with chronic disease. Furthermore, CPX has also been used to determine the cardiopulmonary responses induced by the aging process, by ergogenic aids as well as by exposure to air pollutants (25). Hikers exhibit significant decreases in pulmonary function due to environmental levels of ozone, $\mathrm{PM}_{2.5}$ and aerosol acidity (26). The same finding was reported for amateur cyclists, followed by symptoms related to respiratory discomfort (27). Healthy adults exhibit significant evidence of impairment of aerobic metabolism during exercise at environmental levels of pollution (17).

The present study was designed to evaluate the effects of exercise in environments with the same climatic characteristics but differing in their level of air pollution. For such purpose, we studied 25 healthy firefighters who practiced daily physical exercise and who agreed to do so in two different locations. We do not believe that the selection of firefighters introduced a bias in our study because of previous exposure of these individuals to noxious gases. First, most of the actions of firefighters in Guaruja are not related to fire, since they are responsible for lifeguard activities in this town. Second, those exhibiting respiratory symptoms were
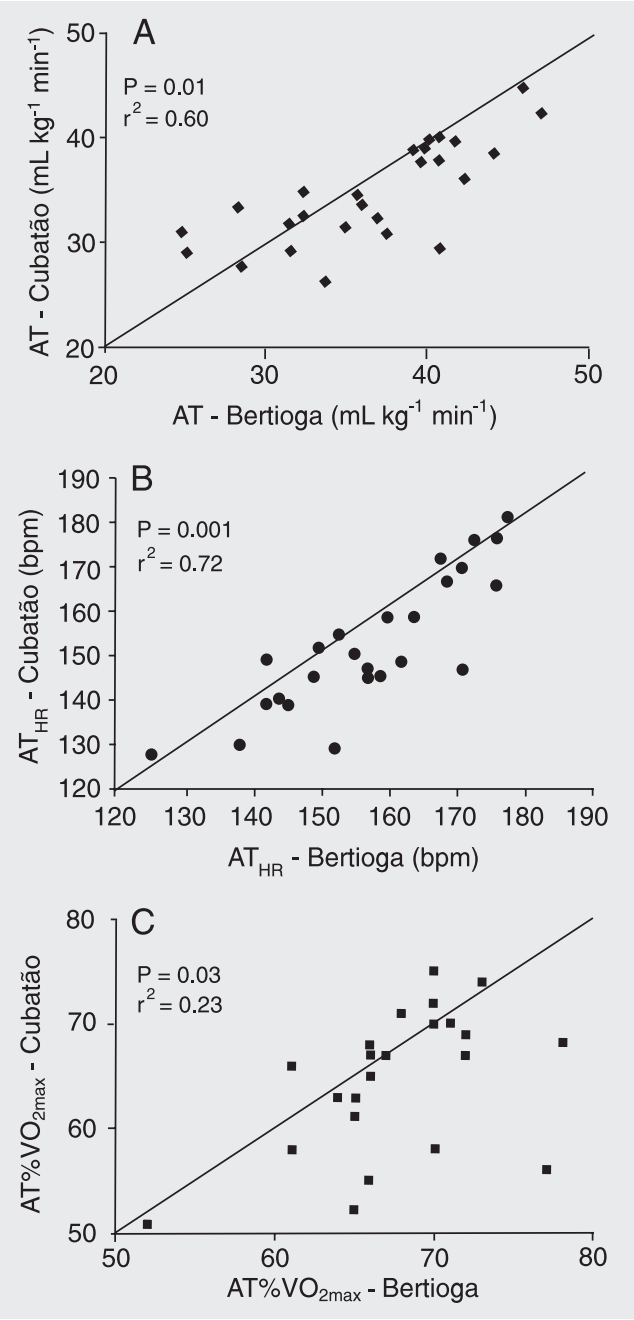

Figure 1. Biological impact of air pollution at Cubatão and Bertioga on cardiorespiratory parameters. Correlations were tested with the Pearson correlation method and $\mathrm{P}$ values (paired $t$-test) are reported in each panel. AT = anaerobic threshold; $\mathrm{AT}_{\mathrm{HR}}=$ heart rate at anaerobic threshold; $\mathrm{AT} \% \mathrm{VO}_{2 \max }=$ percent maximal oxygen consumption at anaerobic threshold. 
excluded from the study. In addition, the crossover design of the study makes it less probable that our findings could be attributed to selection bias.

The importance of our results resides in the fact that even a very short-term period of exposure to environmental air pollutants exposure (about of $1 \mathrm{~h}$ ) decreases the cardiorespiratory performance of a group of clinically healthy young adults with an aerobic power equivalent to the highest level of physical condition, as indicated by $\mathrm{VO}_{2 \max }$ (Table 1). Although the clinical relevance of our findings in this population appears to be limited, these results permit us to suggest that individuals with acute or chronic cardiac or respiratory abnormalities could suffer deleterious changes in cardiorespiratory performance after a brief acute exposure to a polluted environment. This would be true regardless of the severity of their disease, leading to a probable worsening of their condition.

The most significant limitation of this study is the unavailability of direct measurements of air quality in Bertioga. However, our study was not designed to perform any quantitative determination of the threshold levels of pollution that impair exercise capacity. This question could not be addressed even if air pollution data were available, since it is quite probable that such threshold level can be only determined on an individual basis, taking into account the characteristics of health and cardiopulmonary fitness of each subject.

The hypothesis we tested was that acute exposure to environmental levels of air pollution would promote significant abnormalities of functional cardiopulmonary parameters even in healthy young adults. The results showed that the submaximal physiological response to brief acute exposure to air pollutants appeared to be more dramatically worsened than the maximal response, demonstrating that air pollutants can represent an environmental stressor inducing deleterious effects when cardiorespiratory performance is analyzed for the same workload (i.e., at the submaximal level). Activities above AT are predominantly dependent on anaerobic energy output in which critical power represents an important factor. In this situation, the individual capacity to produce energy efficiently via anaerobic glycolysis, to develop elevated muscle power through glycolytic fibers and to buffer $\mathrm{H}^{+}$ions is the most important factor. On the other hand, the ability to produce a high amount of energy depends on the extraction and transport of oxygen to skeletal muscle in activities below AT, with oxygen transport thus representing a pivotal step in these activities (28). Carbon monoxide (CO) is the most significant primary air pollutant, altering the ability of hemoglobin to carry oxygen (29). Hemoglobin also combines with CO to form carboxyhemoglobin, and has 230 times greater affinity for $\mathrm{CO}$ than for $\mathrm{O}_{2}$, indicating that atmospheric air pollutants (especially, $\mathrm{CO}$ ) have a great potential to alter oxygen transport in blood (30).

Since the study was conducted under "real world" conditions, it was not possible to identify a single agent responsible for the effects observed. Moreover, due to its descriptive nature, the study design did not allow us to clarify the mechanisms underlying the functional impairment observed in our sample when exposed to air pollution.

Our results indicate that even a brief acute exposure to moderate levels of air contamination may promote modest but significant physiological abnormalities in clinically healthy young adult individuals during exercise. 


\section{References}

1. Bates DV, Bell G, Burnham C, Hazucha M, Mantha J, Pengelly LD, et al. Problems in studies of human exposure to air pollutants. Can Med Assoc J 1970; 103: 833-837.

2. Folinsbee LJ. Effects of air pollutants on exercise. In: Garret WE Jr, Kirkendall DT (Editors), Exercise and sport science. Philadelphia: Lippincott Willians \& Wilkins; 2000. p 285-297.

3. Paffenbarger RS Jr, Hyde RT, Wing AL, Hsieh CC. Physical activity, all-cause mortality, and longevity of college alumni. N Engl J Med 1986; 314: 605-613.

4. Edgard MG, Aguinaldo G. A corrida para a saúde: poluição ambiental no coração do problema. Rev Bras Ciên Esporte 1997; 18: 111 118.

5. World Health Organization. Guidelines for air quality. http://www. who.int/peh. Accessed November 16, 2003.

6. Saldiva PH, King M, Delmonte VL, Macchione M, Parada MA, Daliberto $M L$, et al. Respiratory alterations due to urban air pollution: an experimental study in rats. Environ Res 1992; 57: 19-33.

7. Dockery DW, Pope CA III, Xu X, Spengler JD, Ware JH, Fay ME, et al. An association between air pollution and mortality in six U.S. cities. N Engl J Med 1993; 329: 1753-1759.

8. Pope CA III, Burnett RT, Thun MJ, Calle EE, Krewski D, Ito K, et al. Lung cancer, cardiopulmonary mortality, and long-term exposure to fine particulate air pollution. JAMA 2002; 287: 1132-1141.

9. Schwartz J. Air pollution and hospital admissions for respiratory disease. Epidemiology 1996; 7: 20-28.

10. Braga ALF, Conceição GMS, Pereira LAA, Kishi HS, Pereira JCR, Andrade MF, et al. Air pollution and pediatric respiratory hospital admissions in São Paulo, Brazil. J Environ Med 1999; 1: 95-102.

11. Braga AL, Saldiva PH, Pereira LA, Menezes JJ, Conceição GM, Lin $\mathrm{CA}$, et al. Health effects of air pollution exposure on children and adolescents in São Paulo, Brazil. Pediatr Pulmonol 2001; 31: 106113.

12. Lin CA, Martins MA, Farhat SC, Pope CA III, Conceição GM, Anastacio VM, et al. Air pollution and respiratory illness of children in São Paulo, Brazil. Paediatr Perinat Epidemiol 1999; 13: 475-488.

13. Martins LC, Latorre MR, Saldiva PH, Braga AL. Air pollution and emergency room visits due to chronic lower respiratory diseases in the elderly: an ecological time-series study in São Paulo, Brazil. $J$ Occup Environ Med 2002; 44: 622-627.

14. Lin CA, Amador Pereira LA, de Souza Conceição GM, Kishi HS, Milani R Jr, Ferreira Braga AL, et al. Association between air pollution and ischemic cardiovascular emergency room visits. Environ Res 2003; 92: 57-63.

15. Peters A, Liu E, Verrier RL, Schwartz J, Gold DR, Mittleman M, et al.
Air pollution and incidence of cardiac arrhythmia. Epidemiology 2000; 11: 11-17.

16. Pope CA, Dockery DW, Kanner RE, Villegas GM, Schwartz J. Oxygen saturation, pulse rate, and particulate air pollution: A daily time-series panel study. Am J Respir Crit Care Med 1999; 159: 365372.

17. Adir $\mathrm{Y}$, Merdler A, Ben Haim S, Front A, Harduf R, Bitterman $\mathrm{H}$. Effects of exposure to low concentrations of carbon monoxide on exercise performance and myocardial perfusion in young healthy men. Occup Environ Med 1999; 56: 535-538.

18. Folinsbee LJ, Raven PB. Exercise and air pollution. J Sports Sci 2006; 2: 57-75.

19. Aronow WS, Cassidy J. Effect of carbon monoxide on maximal treadmill exercise. A study in normal persons. Ann Intern Med 1975;

20. Stanford B. Exercise and air pollution. Phys Sportsmed 1990; 18 : 153-154.83: 496-499.

21. Companhia de Tecnologia de Saneamento Ambiental. Índice de qualidade do ar. http://www.cetesb.sp.gov.br. Accessed August 818, 2000.

22. Barros Neto TL, César MC, Tambeiro VL. Avaliação da aptidão física cardiorrespiratória. In: Ghorayeb N, Barros Neto TL (Editors), O exercício: preparação fisiológica, avaliação médica, aspectos especiais e preventivos. São Paulo: Atheneu; 1999. p 15-24.

23. Shephard RJ. Tests of maximum oxygen intake. A critical review. Sports Med 1984; 1: 99-124.

24. Wasserman K, Mcllroy MB. Detecting the threshold of anaerobic metabolism in cardiac patients during exercise. Am J Cardiol 1964; 14: 844-852.

25. Wasserman K, Hansen JE, Sue DY, Casaburi R, Whipp BJ. Principles of exercise testing and interpretation. 3rd edn. Philadelphia: Lea \& Febiger; 1999.

26. Korrick SA, Neas LM, Dockery DW, Gold DR, Allen GA, Hill LB, et al. Effects of ozone and other pollutants on the pulmonary function of adult hikers. Environ Health Perspect 1998; 106: 93-99.

27. Brunekreef B, Hoek G, Breugelmans O, Leentvaar M. Respiratory effects of low-level photochemical air pollution in amateur cyclists. Am J Respir Crit Care Med 1994; 150: 962-966.

28. Wilmore JH, Costill DL. Physiology of sport and exercise. Champaign: Human Kinetics; 1999.

29. Hlastala MP, McKenna HP, Franada RL, Detter JC. Influence of carbon monoxide on hemoglobin-oxygen binding. J Appl Physiol 1976; 41: 893-899.

30. Armstrong LE. Performing in extreme environments. Champaign: Human Kinetics; 2000. 